\title{
Diosas y madres, el arquetipo femenino en Diego Rivera
}

\section{Goddesses and mothers, the feminine archetype in Diego Rivera}

\author{
Dina Comisarenco Mirkin \\ Universidad Iberoamericana, Ciudad de México \\ dina.comisarenco@gmail.com
}

\section{Resumen}

En el presente trabajo se estudia la representación del arquetipo femenino en la obra mural de Diego Rivera tomando como punto de partida, no sólo su erudita utilización de símbolos alegóricos tradicionales, sino y particularmente, algunas de las experiencias vitales del artista, en particular aquellas relacionadas con el amor filial, con la maternidad/paternidad, y con sus complejas relaciones amorosas con distinguidas mujeres de su época, que de forma más o menos consciente, el artista entretejió con una extraordinaria imaginación poética en sus amplios y complejos programas iconográficos. Se concluye así que el arte mural fue para Rivera no sólo un instrumento de acción política, tal y como normalmente reconoce la crítica especializada, sino también, una oportunidad para elaborar temas personales, en los que paradójicamente alcanza un mayor grado de generalidad y histórica.

Palabras clave: Diego Rivera; Arquetipo Femenino; Diosas; Madres

\section{Abstract}

In this paper I examine the representation of the feminine archetype in Diego Rivera's murals, considering not just his learned use of traditional allegorical symbols, but also, his personal experiences, in particular those in regard to filial love, maternity/paternity, and his very complex amorous relationships with some outstanding women of his time, which in a more or less conscious way, the artist intertwined with extraordinary lyrical imagination in his ample and complex iconographic programs. I conclude that for Rivera, muralism was not only an instrument of political action, such as it is normally recognized by specialized literature, but also, an opportunity to elaborate personal themes, in which paradoxically he reaches a greater degree of universality and transcendence that the one which characterizes his history paintings.

Keywords: Diego Goddesses, Mothers
Rivera, Feminine Archetype,

\section{Introducción}

Frente a la oportunidad de análisis y reflexión que nos ofrece la perspectiva histórica con la que contamos hoy en día, distanciados ya de la imagen pública y política que el mismo Diego Rivera (18861957) y sus principales biógrafos construyeron del artista, surgen nuevas y estimulantes preguntas en relación a las causas de su extraordinario valor poético y artístico, que sin lugar a dudas, trascienden los postulados ideológicos a partir de los cuales el artista orientó conscientemente su obra mural. En este sentido, el someter su obra al escrutinio de perspectivas de estudio diferentes que atiendan a otros niveles de lectura, que incluyan no sólo cuestiones históricas y estéticas, sino también algunos aspectos de índole personal y simbólico, puede resultar una tarea estimulante y revitalizadora. 
En su reciente libro Diego Rivera, luces y sombras, la destacada especialista Raquel Tibol señala que "el inveterado alegorizador que fue Rivera no dejó nunca de utilizar, dentro del realismo, como símbolo, la figura femenina, ya fuera desnuda u ornamentada." (Tibol, 2007, p. 175) Tibol destaca también que:

las alegorías y los símbolos fueron considerados por Rivera como abstracciones, pero no siempre lo fueron en un sentido estricto, pues si bien a veces parecieran alejarse de la motivación temática de la estructura donde están insertos, para producir sobre todo placer estético, no dejan por ello de cumplir una función informativa, de significar algo (...) (Tibol, 2007, p. 175)

En el presente trabajo me propongo explorar algunos de esos significados asignados por Rivera a la figura alegórica femenina y su articulación en relación con el "realismo" de los amplios y complejos programas iconográficos proyectados por el artista en algunos de sus principales ciclos murales realizados a lo largo de las distintas fases de su vida.

Por una parte, la representación de las alegorías femeninas puede entenderse como una narración en paralelo al contenido histórico concreto y principal de su mensaje incluido conscientemente por Rivera como un recurso retórico eficaz para amplificar y lograr una proyección de carácter más universal a su temática nacional. Efectivamente, las asociaciones alegóricas y las alusiones más o menos evidentes y referencias concretas a otros aspectos de la mitología universal y particularmente a distintas leyendas de la cosmogonía prehispánica, es un recurso persuasivo característico de la obra mural de Rivera que está empezando a ser descubierto y estudiado a fondo en relación a algunos de los distintos aspectos de su obra mural, muy particularmente a su visión de la historia.

Por otra parte, la asimilación de las figuras alegóricas de Rivera con mujeres reales de su círculo social, de acuerdo con sus ocupaciones, su interpretación de las respectivas personalidades individuales y especialmente, con las relaciones amorosas que muchas de ellas mantuvieron con el propio artista, otorgan a su obra un carácter auto-referencial normalmente desatendido por la crítica especializada. Se postula en el presente trabajo, que es justamente la auto-exploración subjetiva de algunas de sus experiencias vitales más profundas, aunada al asombro extraordinario y a la admiración más plena de su receptiva mente en relación con los orígenes de la vida, y la admiración del artista por las sobresalientes mujeres que intervinieron en su vida, lo que le permitió "experimentar" intensamente, modificar, construir, y dar forma simbólica al arquetipo femenino a través de las distintas etapas de su desarrollo personal y artístico. En el presente trabajo me propongo demostrar que además del innegable valor histórico de la obra mural de Rivera, y más allá de su controversial y prolífica vida, tanto en el terreno de lo sentimental como de lo político, gran parte de su trascendencia artística y cultural se debe justamente a su extraordinario poder para vivir y simbolizar la realidad psíquica propia de la humanidad, más allá de las determinaciones particulares de los distintos tiempos y lugares, lograda principalmente, no sólo a través de símbolos y narraciones eruditas sino más bien a través de los referentes subjetivos de su obra.

\section{El arquetipo de la feminidad}

De acuerdo con la psicología analítica fundada por el psicólogo y antropólogo suizo Carl Gustav Jung (1875-1961) existe un inconsciente personal, formado por experiencias que no pueden ser aceptadas por el "Yo" porque percibidas como desagradables o temibles son reprimidas, y, también, un inconsciente colectivo, de carácter transpersonal y universal, moldeado por las experiencias más fundamentales y 
reiteradas a través de la historia de la humanidad que aunque constituido por funciones psíquicas inconscientes, conforman los principales modelos de conducta humana. Los arquetipos de la madre, el padre, la familia, el héroe, el viejo sabio, el niño, la persona, la sombra y el hermafrodita, son tan sólo algunos de estos primeros modelos esenciales impresos en el inconsciente colectivo de la humanidad.

De todos ellos, sostiene Jung que la imagen primordial para el ser humano es la de la "Gran Madre", pues todos los seres humanos, más allá de nuestros respectivos géneros, somos hijos de una madre, que ineludiblemente constituye nuestra primera experiencia en el mundo. El arquetipo materno es consiguientemente una imagen interna propia de la mente humana que debido a su universalidad e importancia básica se encuentra presente en innumerables ritos, mitos, símbolos religiosos, sueños, fantasías, y obras artísticas de distinta índole desde la prehistoria hasta la época contemporánea. ${ }^{1}$ Señalaba Jung que:

[C]omo todo arquetipo, el de la madre también tiene una serie casi inabarcable de aspectos [como por ejemplo:] (...) la madre y abuela personales; (...) ; cualquier mujer con la que se tiene relación, incluida el ama de cría o la niñera; (...); en sentido más elevado, figurado, la diosa, especialmente la Madre de Dios, la Virgen ... la meta del anhelo de salvación (Paraíso, Reino de Dios, Jerusalén celestial); en sentido más amplio, la iglesia, la universidad, la ciudad, el país, el cielo, la tierra, el monte, el mar y las aguas (...); la materia, el inframundo y la luna; en sentido más estricto, como lugar de nacimiento y de procreación, los sembrados; el jardín, la roca, la cueva, el árbol, el manantial, el pozo, la pila bautismal, la flor como recipiente (rosa y loto); como círculo mágico (mandala com padma) o como tipo de la cornucopia; en sentido más estricto, el útero, cualquier concavidad (...), la olla ... (Jung, 1934/2002, pp. 78-79).

Para Erich Neumann (1905-60), uno de los más destacados discípulos de Jung, en su extraordinario libro The Great Mother: An Analisis of the Archetype (1974), el arquetipo femenino se origina en el "uroboros" griego ${ }^{2}$ o estado inconsciente en el que lo femenino y masculino, lo positivo y lo negativo, lo hostil y lo amistoso están entremezclados. Más adelante, a través del proceso de individuación, se desarrollan las imágenes de la Buena Madre y de la Madre Terrible y, finalmente, de la Gran Madre que reúne características de las primeras dos. A través del mecanismo de las proyecciones del inconsciente en el mundo externo surgen los símbolos artísticos y los motivos mitológicos y religiosos. Así por ejemplo Sofía es un ejemplo de la Buena Madre, la Gorgona de la Madre Terrible e Isis de la Gran Madre. En una época en que la psicología freudiana se centraba fundamentalmente en el padre, uno de los aportes fundamentales de Neumann fue la descripción del complejo de la Gran Madre como la matriz cultural fundamental de nuestra psique (1974). Neumann señalaba que el recorrido de la historia humana colectiva encuentra su paralelo en la historia personal del individuo que tiene que atravesar por las mismas etapas arquetípicas que determinaron la evolución de la conciencia en la vida humana. El individuo sigue en su propia vida el camino que la humanidad ha recorrido antes que él, viviendo así una

\footnotetext{
${ }^{1}$ Para un excelente análisis del arquetipo femenino en el arte contemporáneo ver (Saiz Galdós; Fernández Ruiz; Estramiana, 2007).

2 "El uroboros es un símbolo ancestral que muestra un gusano, una serpiente o un dragón engullendo su propia cola y formando así un círculo. Expresa la unidad de todas las cosas, las materiales y las espirituales, que nunca desaparecen sino cambian de forma perpetua en un ciclo eterno de destrucción y nueva creación" (Wikipedia. La enciclopedia libre. Extraído el 18 de octubre de 2010 de http://es.wikipedia.org/wiki/Uróboros).
} 
batalla simbólica entre las fuerzas matriarcales y las patriarcales, las fuerzas regresivas y las progresivas, las referencias afectivas y las abstractas, que le permiten desarrollar su sistema consciente.

A pesar del consabido donjuanismo de Rivera en su vida íntima; de no haber escapado completamente a muchos de los estereotipos y prejuicios propios de su entorno histórico y cultural, de no haber sido, según palabras de la misma Tibol, "un precursor en planteamientos que se opusieran a la discriminación de la mujer" (2007, pp. 179-180) y de la evidente sublimación y erotización con la que Rivera muchas veces interpretó a la figura femenina, muchas otras de sus imágenes, particularmente las incluidas en su obra mural, originadas en algunas de sus experiencias psicológicas más profundas, y en la admiración y el reconocimiento a las grandes mujeres que impactaron en su vida, expresan arquetipos de carácter universal, revelan su proceso de construcción tanto cultural como personal, y reintegran a la mujer su sacralidad y poder creador, generalmente ausentes o relegados en gran parte de las manifestaciones artísticas de la época moderna. ${ }^{3}$

\section{Los orígenes del arquetipo en la historia personal de Rivera}

Destacaba el pensador francés Gastón Bachelard (1884-1962) que "el amor filial es el primer principio activo de la proyección de las imágenes, es la fuerza proyectora de la imaginación, fuerza inagotable que se apodera de todas las imágenes para ponerlas en la perspectiva humana más segura: la perspectiva maternal." Señalaba también que:

Otros amores vendrán, por supuesto, a injertarse en las primeras fuerzas amantes, pero todos esos amores no podrán destruir jamás la prioridad histórica de nuestro primer sentimiento. La cronología del corazón es indestructible. Como consecuencia, cuanto más metafórico sea un sentimiento de amor y de simpatía, más necesario le será ir a extraer sus fuerzas de un sentimiento fundamental. En esas condiciones, amar una imagen es siempre ilustrar un amor; amar una imagen es encontrar en el saber una nueva metáfora para un amor antiguo. Amar el universo infinito es darle un sentido material, un sentido objetivo a la infinitud del amor por una madre (Bachelard, 1942/2003, p. 177).

A continuación, vamos entonces a tratar de acercarnos a las primeras fuerzas amantes, al amor antiguo, al amor de Rivera por su madre, como base para acercarnos a algunos de sus amores posteriores más significativos, a algunas de las destacadas mujeres que fueron contribuyendo a transformar y a dar forma al arquetipo femenino del artista y, principalmente a sus cuantiosas, variadas y profundas metáforas artísticas a través de las cuales Rivera lo expresó en su obra mural.

Antes del nacimiento de Diego y su hermano gemelo el 8 de diciembre de 1886, el matrimonio Rivera había experimentado tres embarazos que terminaron muy tristemente en bebés nacidos muertos. El parto doble con el que Diego llegó a la vida fue también extraordinariamente difícil pues después de su nacimiento la madre sufrió una hemorragia que complicó el nacimiento del segundo bebé, Carlos María. La madre quedó inconsciente durante muchas horas y según narran sus familiares, se pensó que había muerto. Ante las dificultades pronosticadas se había previsto que en un caso límite se salvaría a la

\footnotetext{
${ }^{3}$ Para una perspectiva feminista de los análisis junguianos ver Douglass (1990) y Rowland (2002).
} 
madre y no a los hijos, pero el destino parecía haber dispuesto lo contrario. La inmensa alegría que produjo la sorprendente recuperación de la madre y el por tanto tiempo anhelado nacimiento de los gemelos, se ensombreció tan sólo 18 meses más tarde cuando el bebé Carlos María falleció.

Como consuelo para aliviar el dolor de la madre, se le aconsejó entonces que estudiara una carrera que pudiera mantenerla ocupada. La Sra. María del Pilar Barrientos de Rivera decidió instruirse en obstetricia y muy pronto se convirtió en una partera activa. La soledad de Diego, la culpa ${ }^{4}$ y los horrores asociados con la muerte de su hermano gemelo deben haberse profundizado cuando su madre comenzó a ausentarse del hogar para asistir a otras mujeres en el misterioso proceso de dar a luz y cuando por su mala salud, a una edad muy temprana, fue enviado a vivir por un tiempo lejos de su familia.

Recordaba Rivera que cuando tenía apenas dos años de edad su salud era efectivamente tan precaria, que el médico familiar aconsejó que lo enviaran al campo para evitar el trágico destino de su hermano. En sus propias palabras dijo que "por esta razón, mi padre me entregó a Antonia, mi nana india. Antonia, a quien desde entonces quise más que a mi propia madre, me llevó a vivir con ella en las montañas de la sierra," (Rivera, Diego y March, Gladys, 1960/1963, p. 19) palabras que son un claro testimonio del sentimiento de abandono y del problemático lazo madre-hijo experimentado durante aquellos cruciales años de la vida del futuro artista que sin lugar a dudas dejaron una fuerte huella que habría de perseguirlo a lo largo de su vida y obra.

Recordaba Rivera que cuando a la edad de cinco años de edad regresó de las montañas su madre estaba embarazada y le dijo que el nuevo bebé llegaría por tren en una caja. Rivera recordaba que ese día esperó en la estación y observó todos los trenes

[P]ero no llegó ninguna caja para mi mamá. Cuando regresé a mi casa y descubrí que mi hermana María había nacido durante mi ausencia me puse furioso.

Frustrado y colérico, cogí una ratona preñada y le abrí el vientre con unas tijeras. Quería saber si había ratoncitos dentro de ella. Cuando descubrí los fetos de los ratones, me abalancé al cuarto de mi madre y se los tiré en plena cara, gritando:

- Mentirosa, mentirosa. (Rivera y March, 1960/1963, p. 20).

Incluso tomando en cuenta la exageración y la fabulación características del Rivera adulto que narraba la anécdota, el relato resulta un testimonio importante de los sentimientos si no del Rivera niño, definitivamente sí del Rivera artista que ahora nos ocupa y que a lo largo de toda su vida se vio impelido a investigar y a representar los orígenes de la vida humana como parte esencial del arquetipo femenino. Si bien las fechas aproximadas asignadas a los dibujos infantiles de Rivera no coinciden exactamente con la anécdota aquí narrada, resulta interesante observar que la forma con la que el niño interpretó el tren visto de frente se asemeja a la de un vaso o jarra de cuerpo redondo, símbolo característico del arquetipo materno, que responde perfectamente a la fantasía con la que se había querido distraer su mente infantil, evidentemente con muy poco éxito.

\footnotetext{
${ }^{4}$ Muy comúnmente cuando los niños pequeños se enfrentan con la muerte de un hermano, como inconscientemente en algún momento la habían deseado, temen haberla ocasionado y se sienten culpables. Estas dramáticas situaciones familiares tempranas deben haber influido en el desarrollo psicológico de Rivera dejándolo particularmente vulnerable frente al tema de la muerte y a su incomprensible cercanía con la vida.
} 
Bertram Wolfe señalaba que tras el referido episodio, su madre quedó convencida de que había traído al mundo a un monstruo. Su padre en cambio, tras cuestionarlo sobre:

[S]i su deseo de comprender el mecanismo del animal había sido tan fuerte como para hacer caso omiso del dolor que su curiosidad infligiría al animalito (...) le suministró información sobre el sexo y el nacimiento y le mostró libros que contenían reproducciones anatómicas [que Rivera comenzó a dibujar. Señala acertadamente el mismo autor que] sus juveniles exploraciones en la anatomía de un ratón, fueron el prolegómeno de un interés cultivado a lo largo de su vida, por la observación, la disección y el análisis, en aras de su síntesis pictórica." (Wolfe, 1963/1997, p. 32).

Tiempo después, cuando Rivera tenía 8 años y su hermana María 3, nació otro hermanito, Alfonso, que murió a los 8 días de edad. Bertram Wolfe cuenta una impactante historia que a su vez le fue narrada a él por la misma María, según la cual los dos niños fueron descubiertos en pleno velorio en medio de un juego infantil que terminó en una macabra disputa por el cuerpecito del bebé muerto (Wolf, 1963/1997, pp. 36-37). Más adelante Rivera aprendió a canalizar su interés científico por los orígenes de la vida y sus apasionadas emociones en formas más constructivas y se dice que a una edad muy precoz comenzó a mirar y más tarde a leer algunos de los libros de obstetricia de su madre, muchos de los cuales todavía se conservan en el Museo de la Casa Azul, y que junto con otros que más adelante se añadieron a la colección, sirvieron de base para algunas de las representaciones de la maternidad tanto en la obra de Frida como en la del propio Rivera que trataremos aquí.

De acuerdo con Jung, si una persona no encuentra satisfacción en relación con el arquetipo materno en su propia madre, a lo largo de su vida tiende a buscarlo a través de otras figuras sustitutas como la madre tierra, la patria, o la revolución, temas y expresiones simbólicas ampliamente recurridas en la vida y en la obra artística de Rivera. Señala también el autor que el complejo materno en los hijos varones puede derivar a veces en el donjuanismo, como síntoma claro de la insaciable búsqueda del arquetipo materno. Jung destaca también algunos aspectos positivos del así llamado complejo materno, tales como:

[L]a violencia frente a la estupidez, la intransigencia, la injusticia y la abulia; una voluntad de sacrificio, rayana en el heroísmo, para todo lo que se ha reconocido como bueno; tesón, inflexibilidad y perseverancia; una curiosidad a la que ni siquiera asustan los enigmas del universo; un espíritu revolucionario, finalmente, que les edifica a los otros hombres una nueva casa o que le implanta al mundo un nuevo rostro, (Jung, 1934/2002, p. 83)

Características todas que parecen escritas para caracterizar muy fielmente al mismo Rivera. Podemos especular así, que de acuerdo con los difíciles comienzos en relación con la constatación del arquetipo materno, una parte importante de la vida y de la obra del artista pueden entenderse como parte de esta búsqueda insaciable por el primer amor, el más antiguo e importante, la madre, al que paulatinamente sus posteriores amores irían transformando y re-construyendo. 


\section{La buena madre indígena}

Pese a los dramáticos momentos vividos por la familia Rivera tras la muerte del gemelo de Diego, los cuidados de Antonia, la nana indígena, le permitieron seguir viviendo el arquetipo de la buena madre, como figura protectora y nutriente. El artista adulto la recordaba como

Una mujer alta, tranquila, que andaría por los veinticinco o veintiséis años; tenía unos hombros maravillosos, caminaba erguida con elegancia sobre piernas magníficamente esculpidas y su cabeza se mantenía altiva como si estuviera soportando una carga. Visualmente era el ideal de un artista de lo que es la mujer indígena clásica, y la he pintado muchas veces de memoria con su largo vestido rojo y su chal azul (Rivera y March, 1960/1963, p. 19).

El tema de la maternidad indígena, como paradigma del amor, la protección, y la nutrición, fue para Rivera, no sólo una más de sus tantas expresiones idealizadas del pasado prehispánico y de la realidad de la población indígena de su México contemporáneo que amaba profundamente, sino también, una representación autobiográfica, expresión clara y contundente del sentimiento de agradecimiento y ternura hacia Antonia, que como señalaba el artista, lo acompañó durante toda su vida.

Además de la evidente alusión al mestizaje nacional explicitada por las diferentes características raciales de algunas de sus escenas de maternidades, los blancos y regordetes bebés de algunas de sus imágenes, parecen ser autorretratos retrospectivos del artista muy felizmente protegido por su nana indígena que amorosamente lo carga envuelto en un rebozo. El amor de Antonia sin lugar a dudas influyó en la identificación de Rivera con la causa indígena mientras que la experiencia del desamor materno, ocasionada por las dramáticas circunstancias antes descritas, lo llevarían, correlativamente, a rechazar las ideologías de carácter conservador que el artista asociaba con su propia madre.

El carácter benéfico del arquetipo materno fue capturado por Rivera en abundantes imágenes de mujeres indígenas en actitud protectora y tierna con sus niños o bien a través de metáforas de jarras de barro, y mujeres cargando y ofreciendo abundantes frutas que simbólicamente enfatizan las funciones de gestación y nutrición propias del cuerpo humano femenino. El símbolo de la jarra redonda como metáfora del útero contenedor, protector, nutriente y transformador asociado con el cuerpo femenino aparece en innumerables obras artísticas alrededor del mundo. A veces la jarra misma adquiere la forma de la mujer y a veces el tema se duplica y la mujer-vaso porta un vaso. Si bien la cerámica, que utiliza el barro, la tierra, en muchas culturas es una actividad exclusivamente femenina, en su imagen Rivera, siempre consciente y orgulloso del rol masculino tanto en la creación como en la procreación, incluye también alfareros hombres. Las frutas aluden a la función nutriente, una vez más como metáfora visual del cuerpo humano femenino, entretejida como todas sus "abstracciones" con la narración histórica, en este caso con la obtención de la justicia social con la que soñaba el artista.

En agosto de 1916, a la edad de 30 años, mientras vivía en Francia, Rivera se convirtió en padre cuando su primera esposa Angelina Beloff (1879-1969), dio a luz a un bebé varón al que llamaron como al artista, Diego. Angelina recordaba que la actitud de Rivera frente a su primera paternidad fue ambivalente: cuando recibió la noticia del embarazo, "Rivera estaba muy molesto ante la perspectiva de tener que jugar el rol de padre. Insistía en que el bebé le privaría de la paz y que además, no podrían mantenerlo," (Rivera y March, 1960/63, pp. 194-195) pero que una vez nacido el niño "Rivera parecía muy feliz y me decía que quería más hijos" (Beloff, 1986, p. 56). Este hecho importantísimo en la vida del 
artista dio lugar a algunas de las primeras imágenes de reproducción humana en el repertorio iconográfico de Rivera, en dos pinturas de caballete al óleo: Mujer en verde (Retrato de Angeline embarazada) y Maternidad (1916) donde en palabras del mismo Rivera pintó a Angelina "con nuestro hijo Diego, con el pecho descubierto y el niño mamando" (Rivera y March, 1960/1963, p. 95). Las dos pinturas fueron realizadas en el estilo cubista sintético que por aquel entonces Rivera estaba explorando y no muestran trazas de un impacto emocional particularmente relevante, salvo por las suaves y prominentes líneas curvas que sirven para representar el cuerpo protector y nutriente de la figura materna rompiendo con la geometría rectilínea típica del estilo. A pesar de la declaración de Angelina, las relaciones de la pareja sufrieron entonces una fuerte crisis. Rivera y Angelina se separaron al poco tiempo de nacido el bebé, y el artista se fue a vivir por un corto tiempo con otra mujer, Marevna Vorobieva (1892-1984), con quien según su testimonio tuvo otra hija, Marika, a quien el artista nunca reconoció como propia. Finalmente se reconcilió con Angelina, pero apenas unos meses después el pequeño Diego murió, víctima de su pobre salud y de las privaciones causadas por la guerra.

Tal vez Rivera, de acuerdo con su difícil relación temprana con su madre, no estaba entonces psicológicamente maduro para la paternidad. La prematura muerte de su hijo no le dio oportunidad alguna para superar su rechazo y abandono inicial. Rivera reconoció más tarde que "la muerte de este inocente [le] deprimió terriblemente" (Rivera y March, 1960/1963, p. 56). Por otro lado, y aunque sólo sea a nivel inconsciente, el trágico evento, debe haberle hecho reconsiderar sus sentimientos infantiles frente a la muerte de su hermano ocurrida a aproximadamente la misma edad que la de su pequeño hijo, y en particular lo debe haber ayudado a entender por fin la inmensa tristeza que durante su infancia temprana embargaba a sus padres. Tal vez entonces pudo por lo menos en parte redirigir el enojo experimentado frente al desgarrador sentimiento de desamor materno racionalizándolo ahora como una desafortunada consecuencia de la tragedia familiar, ayudándolo así, a pesar del dolor, a reconciliarse con su propia madre y consiguientemente con el arquetipo femenino y a madurar lo suficiente como para aceptar su pronta y futura paternidad con mayor entusiasmo y responsabilidad.

\section{La Madre Tierra}

Rivera regresó a México en julio de 1921 y poco tiempo después, en junio de 1922, se casó con Lupe Marín (1897-1981) a quien representó tres veces en su primer mural La Creación (1922) como encarnación alegórica de "la mujer", "la fortaleza" y "el canto". ${ }^{5}$ Durante sus siete años de vida juntos la pareja procreó dos hijas, la primera Guadalupe, nacida en 1924 y la segunda, Ruth, en 1927. Durante estos años Rivera pintó algunos de sus trabajos más célebres en el ciclo mural para la Universidad Autónoma de Chapingo, especialmente los ubicados en el salón de actos emplazado en la antigua capilla, que contienen por un lado un nuevo y personal homenaje a la experiencia del artista como padre denotando una nueva conciencia de su poder como creador tanto en el reino artístico como en el humano, y por otro, y principalmente, a la mujer asociada ahora principalmente con las divinidades femeninas de la fertilidad y la Madre Tierra.

En el sotocoro que precede a la nave propiamente dicha, Rivera representó a una mujer sentada con dos mazorcas de maíz frente un niño que con los ojos cerrados sueña con la abundancia del maíz, las manzanas y el trigo. En otro de los muros del recinto Rivera personificó al agitador o sembrador de

\footnotetext{
${ }^{5}$ Para una identificación completa de las modelos utilizadas por Rivera en La Creación ver Roura (1999).
} 
sueños que incita a la transformación social y en el lado opuesto a los mártires agrarios, Emiliano Zapata (1879-1919) y Otilio Montaño (1877-1917) que con su sangre fecundan a la Tierra y al movimiento social. En el plafón los símbolos del nuevo orden anticipan el triunfo revolucionario.

Resulta interesante señalar, que como acertadamente han destacado los especialistas Antonio Rodríguez y Raquel Tibol, la figura femenina con las mazorcas de maíz en sus manos evoca a la diosa azteca del maíz Chicomecóatl. Una representación de la misma diosa había aparecido ya en un detalle del panel de Rivera titulado la Mecanización del campo, de la Secretaría de Educación Pública, dando inicio así, a la serie de alusiones y de representaciones literales de diosas prehispánicas que a lo largo de su vida utilizaría Rivera para dar forma al arquetipo femenino. Además de la referencia prehispánica abstracta, una vez más Rivera entretejió el significado profundo del mito con la narración histórica en turno. Los ritos religiosos en honor de la diosa del maíz, implicaban sacrificios humanos. En las pinturas de Rivera dichos sacrificios fueron re-interpretados a través de la representación de los mártires agrarios revolucionarios, sacralizando así y otorgando un sentido histórico profundo a sus patrióticas y dramáticas muertes. ${ }^{6}$

En la nave propiamente dicha continua la narrativa paralela en la que se da cuenta por una parte de la transformación social de México, y por la otra, de su equivalente metafórico en el así llamado canto a la tierra o evolución natural, en la que Rivera creó una serie de extraordinarios desnudos alegóricos, expresión simbólica fuerte y elocuente del arquetipo femenino en relación con la agricultura y con la Madre Tierra que partiendo de la tierra dormida en el antiguo coro se desarrollan hasta llegar a la tierra fecunda en la pared correspondiente al antiguo altar. ${ }^{7}$

La narración análoga se desarrolla en las paredes laterales del salón de actos: en la primera crujía, a la formación del liderazgo revolucionario, le corresponde en el muro opuesto las fuerzas subterráneas y en la parte superior, la representación simbólica de la tierra oprimida frente al hombre emergente; y finalmente, en la bóveda, los elementos. En la segunda crujía a la organización clandestina del movimiento agrario y el comienzo de las hostilidades, le corresponde la germinación, y en la bóveda en busca del camino. En la tercera, a la continua renovación de la lucha revolucionaria, le corresponde la floración y en la bóveda, la revelación del camino. Finalmente, en la cuarta crujía Rivera representó el triunfo de la Revolución frente a los frutos de la tierra y los frutos de la cosecha, para culminar en el muro final principal, que originalmente debe haber correspondido al altar, con la representación de la tierra fecunda y la familia humana y, en la bóveda, la legal posesión de las bondades de la tierra.

\footnotetext{
${ }^{6}$ De Acuerdo con el cronista Bernardino de Sahagún, en los ritos aztecas cuando brotaba el maíz se iba a los campos para "buscar al dios del maíz", una planta que se traía a la casa para darle ofrendas como si se tratase del mismo dios. En la noche se la llevaba al templo de Chicomecóatl, donde se reunían las muchachas de edades diferentes (niñas, adolescentes y jóvenes) que llevaban haces de siete espigas de la cosecha anterior envuelto en papel rojo salpicado de hule, llamadas chicomólotl, como la diosa. Tres meses más tarde, cuando la cosecha ya estaba madura, una muchacha que personificaba a Xilonen, el maíz nuevo, era decapitada. Dos meses después, cuando se terminaba la cosecha, se sacrificaba a una mujer que personificaba a la diosa Toci, "nuestra madre", decapitada y desollada. Un sacerdote se envolvía con su piel y un trozo de muslo era llevado al templo del dios del maíz Cinteotl, donde otro sacerdote se hacía con él una máscara. Luego se la trataba como una parturienta, porque probablemente el sentido de este rito era que Toci, renacía en su hijo el maíz seco, en los granos que iban a ser el alimento del invierno. (Mircea Eliade, 1982, pp. 310-11).

${ }^{7}$ En palabras del mismo artista: "En la capilla misma representé los procesos de la evolución natural. La pared de abajo estaba dominada por un gran desnudo femenino, uno de los varios que simbolizaban la Tierra Fecunda, y mostrado en armonía con el hombre, cuyas funciones en la agricultura las representé haciéndolo empuñar los implementos de sus trabajos. Dentro de la tierra mostré espíritus que usaban sus fuerzas para ayudar al hombre. Uno, por ejemplo, era una esfinge saliendo de su llameante cueva con los brazos extendidos para coger los volantes espíritus de los metales y ponerlos al servicio de la industria" (Rivera y March, 1963, pp. 108-109).
} 
Con respecto a sus imágenes alegóricas de Chapingo, Rivera expresó que:

el tema alegórico o simbólico, o tema abstracto, permite desprender de la esclavitud exterior el asunto realista y realizar lo necesario para que, de acuerdo con los muros que la sustentan y las fuerzas internas de la arquitectura y las necesidades de luz y sombra de sus accidentes, la pintura decorativa sea en sí misma "verdad"; ya mi maestro Picasso dijo mejor que nadie que en "pintura se trata de realizar una verdad por medio de una mentira" (Tibol, 2007, p. 192).

La relación entre el cultivo de la Tierra y la mujer es muy remota y extendida. Ligadas biológicamente a la nutrición y a la provisión de alimentos, se piensa que tal vez, por la capacidad de observación de los procesos de gestación en su propio cuerpo y de las actividades domésticas, son quienes descubrieron la agricultura y quienes originalmente se dedicaron a dicha actividad. Algunos de los principales mitos del mundo antiguo corroboran la ancestral asociación de la mujer y la agricultura pues la Isis egipcia, la Ishtar mesopotámica, la Démeter griega, la Ceres romana, y la misma Chicomecóatl prehispánica se dice que enseñaron a los hombres a plantar el grano.

Lo que resulta extraordinariamente original y expresivo en la obra de Rivera es el paralelo visual que logró establecer entre el crecimiento de las plantas, y las distintas etapas de la gestación humana representadas no por embriones en desarrollo, sino por el cuerpo femenino desnudo, dormido o virgen en el inicio, el despertar sexual emergiendo de la tierra como las raíces, atravesando distintos estadios de evolución en los espacios curvos que recuerdan a la placenta materna del panel de la germinación, las poéticas imágenes de la floración y sus metáforas del proceso del alumbramiento, y finalmente, como epítome de todo el proceso evolutivo, la plenitud del embarazo representado por la tierra fecunda.

Decía Paracelso (1493-1541) revolucionario médico y alquimista renacentista profundamente admirado por Rivera que:

[L]a floración de la mujer se da cuando concibe. En esa hora está la floración, y a la flor sigue el fruto, es decir: el hijo (...) Cada árbol que florece por el fruto que va a madurar en él, y el árbol que no esconde fruto alguno no florece tampoco (...) Si una virgen florece alguna vez, tendría que dar también fruto (...) Porque así es la naturaleza de la mujer, que se transforma en cuanto concibe; y entonces todo es para ella como un verano, en el que no hay nieve, escarcha ni invierno, sino tan sólo placer y alegría (1995, p. 79).

El paralelo con el canto a la Tierra del ciclo de Chapingo es sorprendente.

Por otra parte, la solidaridad que existe entre lo telúrico y lo humano, constituye una metáfora muy recurrida entre las primeras sociedades agrícolas. En distintos ritos y textos se identifica a la mujer con la tierra arable y el surco, al órgano genital masculino con el arado, y al trabajo agrícola con el acto generador. Así por ejemplo entre los griegos, cuenta Homero en la Odisea que la diosa Démeter se unió a Jasón al comienzo de la primavera para procurar una rica floración de los campos.

La connotación sexual de los frescos de Rivera resulta todavía más clara al recordar las principales modelos femeninas retratadas por el artista en sus distintos roles simbólicos. Para las alegorías de la Tierra Dormida y para Germinación posó la fotógrafa y activista anti-fascista, Tina Modotti (1896-1942), que en ese entonces mantenía una relación amorosa con Rivera, mientras que para representar la Tierra 
Fecunda y posiblemente también para la Tierra Esclavizada por el monopolio lo hizo su esposa Lupe Marín, que como referimos más arriba, estuvo dos veces embarazada durante la realización del ciclo mural. ${ }^{8}$ En este sentido, los murales de Chapingo representan un verdadero homenaje al hombre, en particular al mismo artista, entendido como el labrador de la naturaleza, y principalmente a la mujer, y a su poder y fuerza creadora inagotable asociada desde tiempos inmemoriales con el concepto de la Madre Tierra.

El arquetipo femenino aparece también representado en Chapingo a través de la figura de las plantas de maíz y del árbol, en algunas de las imágenes que simbolizan la transformación social, particularmente en las referidas a los mártires agrarios y en la del entierro del líder revolucionario. En estos casos, el arquetipo femenino, se alude en su sentido poderoso de naturaleza dual como dadora de vida y de muerte, pero principalmente para simbolizar el carácter cíclico de la evolución cósmica, de la muerte y la regeneración, y del sentido profundo de la Revolución social. En el himno homérico, se cantaba ya "a la Tierra, madre universal de sólidos cimientos, abuela venerable que nutre sobre su suelo todo lo que existe (...) a ti te corresponde dar vida a los mortales, así como quitárselas ..." y Esquilo, glorificaba a la tierra "que pare a todos los seres, los nutre y después recibe de nuevo al germen fecundo" (Eliade, 1964/1982, p. 220). Nacer es salir del vientre materno o de la tierra, y morir es volver a ella. Las plantas de maíz y el árbol de los frescos simbolizan por un lado el producto de la tierra fertilizada por los mártires revolucionarios pero también el arquetipo materno que gracias a su poder vital regenerador, es el ente encargado de ofrecer descanso y renovación para que los héroes finalmente regresen a la vida. Más adelante volveré a tratar el arquetipo femenino representado como árbol en la obra de Rivera con otras connotaciones y matices.

\section{La serpiente}

En la decoración de la Secretaría de Sanidad y Asistencia en la ciudad de México, Rivera pintó, en 1929, Salud y vida, un conjunto de desnudos alegóricos femeninos: la Vida entre el sol y la luna en el plafón del lado norte; la Salud con una estrella roja, en el plafón sur; la Fortaleza y el Conocimiento en el muro oriente; y la Continencia y la Pureza, en el poniente. El ciclo se complementa con pinturas sobre las paredes con plantas floridas y manos monumentales que sostienen espigas de trigo y girasoles en flor, junto con otros símbolos de la fecundidad y de la germinación del tipo de los representados en Chapingo.

A mediados de julio de 1928, Rivera, ya separado de Lupe, había conocido a Frida Kahlo, a quien poco tiempo después habría de retratar en el panel de la distribución de armas del patio de las Fiestas de la Secretaría de Educación Pública, capturando así su personalidad combativa, que como habría de demostrar a lo largo de su vida, iba mucho más allá de su activismo político concreto. La pareja se casó en agosto de 1929 mientras Rivera trabajaba todavía en los frescos de la Secretaría de Sanidad y según relata el amigo y biógrafo de Rivera, Bertram Wolfe, "Frida persuadió a Rivera de que su hermana Cristina posase para el idílico y travieso Conocimiento (...)"(1963/1997, p. 203) y también para la alegoría de la Vida, el desnudo con el rostro hacia abajo del techo .

\footnotetext{
${ }^{8}$ Otras modelos retratadas en el ciclo mural fueron, la folklorista Concha Michel (1899-1990) pionera del movimiento feminista mexicano, quien posó para la alegoría del agua incluida en el muro principal; Luz Martínez, para el desnudo femenino de la familia humana; y para los desnudos de las fuerzas subterráneas la modelo fue Graziella Garbalosa. Para los desnudos masculinos posaron sus ayudantes, para el de espaldas del muro frontal Máximo Pacheco y para el del muro lateral con los brazos en alto Pablo O'Higgins.
} 
A juzgar por las imágenes femeninas representadas en este ciclo mural pareciera que para esta etapa, Rivera, ya definitivamente consagrado como artista y con su nueva esposa y compañera, la sufrida pero también imbatible Frida, continúa elaborando sobre el arquetipo femenino, más independiente ahora de las imágenes derivadas directamente de su propia madre, de su nana indígena, y de la idea de fertilidad tal y como la había representado en Chapingo, para seguir aludiendo a la buena madre pero asociada ahora con una imagen más abstracta y poderosa, una madre más grande que la madre personal, asociada con las virtudes de la fortaleza, la pureza, la sabiduría y la prudencia. Resulta interesante señalar, que la pureza aparece representada junto a un claro manantial de agua mientras que las alegorías de la sabiduría y la prudencia, lo hacen acompañadas de serpientes, otros dos de los aspectos que a través del tiempo ha tomado el arquetipo femenino.

Mucho más allá de su simbolismo fálico evidente, la serpiente fue también, uno de los símbolos más antiguos del arquetipo femenino. En la civilización egipcia, la cobra udjet, en la griega pre-clásica las diosas serpientes y en la clásica, algunas de las representaciones de Artemisa, Perséfone y Atenea demuestran su asociación original con la mujer en su aspecto inicial positivo, antes de ser apropiada por la tradición bíblica y transformada en el símbolo del pecado original. En la mitología prehispánica Cihuacóatl era conocida como la "mujer serpiente", y uno de los atributos más característicos de Coatlicue era el de "la de falda de serpientes".

\section{La patria}

Otro aspecto característico del arquetipo femenino es el de la patria. En este sentido resulta interesante considerar las dudas y cambios que aquejaban al artista en relación con las imágenes que encarnan dicho aspecto. Efectivamente si bien la alegoría de la patria como figura femenina era parte del proyecto original de por lo menos tres de sus obras murales, sólo llegó a concretarse en versión final en una solamente.

En uno de los bocetos originales de Rivera para el muro central de la escalera de la Historia de México del Palacio Nacional (1929-39), el pintor había incluido inicialmente la figura alegórica de una mujer como la madre patria, cobijando al trabajador y al campesino. Resulta muy revelador para entender el cambio recordar las palabras de Tibol según las cuales Rivera consideró que dicha alegoría era:

políticamente falsa, puesto que México todavía no era una madre que diera alimento a los trabajadores y a los campesinos [por lo tanto] eliminó esa figura y la reemplazó, entre junio y octubre de 1931, con la figura de un trabajador que muestra a los mártires de la revolución agraria (Emiliano Zapata y Felipe Carrillo Puerto) el camino hacia el futuro desarrollo industrial” (Tibol, 2007, pp. 217-218).

La asociación de la figura materna con la patria era evidentemente clara para Rivera quien una vez más así, a través de las abstracciones alegóricas construía a través de abstracciones, las "verdades" de sus narraciones históricas.

También en el caso de La elaboración de un fresco y como se construye una ciudad (1930-31), proyectado para la School of Fine Arts de California, hoy San Francisco Art Institute, en San Francisco, California, la alegoría femenina preliminar fue reemplazada por una figura masculina, en este caso por la de un trabajador hombre, de tamaño monumental que aparece dando vuelta a una válvula que parece 
parte del mecanismo del edificio, al lado del autorretrato del mismo Rivera, sentado en los andamios, de espaldas al espectador, como un trabajador más.

En cambio, en la obra titulada Alegoría de California (1931), realizada para el Exchange's Luncheon Club, San Francisco Pacific Stock Exchange, también de San Francisco, California, una figura alegórica femenina sí llegó a personificar al próspero y liberal estado norteamericano en sus versiones tanto preliminares como final. La "atlética democracia" de Walt Whitman (1819-1892), celebrada en su extraordinaria poesía, que era profundamente admirada por Rivera, parecía hacer crecer ciudades, rascacielos, carreteras y caminos, desarrollar la agricultura y la industria, construir barcos y aviones, y como resultado, traer prosperidad a la gente y transformar la vida para bien. Compartiendo la intención de crear una epopeya de los pueblos, el panteísmo y el sensualismo propios del poeta norteamericano, también Rivera se propuso celebrar en su fresco la vida moderna del país del norte, literalmente a través, del retrato alegórico de una atleta, Helen Wills Moody, famosa campeona de tenis de aquella época. Aunque el retrato alegórico causó reacciones encontradas en el público norteamericano contemporáneo, la alegoría se mantuvo hasta en su versión final. ${ }^{9}$ Una vez más, asociando la figura femenina con las riquezas de la Tierra propias del arquetipo, la monumental imagen alegórica sostiene con sus manos frutas, mazorcas de maíz, espigas de trigo y minerales.

La figura alegórica de la patria o en este caso del estado californiano de Rivera, pese a tener puntos de contacto con la ancestral tradición iconográfica que solía encarnarlas en aparatosas figuras femeninas llenas de atributos simbólicos abstractos, se acerca más a la concepción que había expresado el poeta Ramón López Velarde (1888-1921), otro de los grandes escritores admirado por Rivera, en su famoso ensayo la Novedad de la patria y en su poema La suave patria, textos clásicos donde la describía como humilde, de carácter íntimo y maternal. Anticipaba así el artista la imagen de la patria que años más tarde expresaría Frida en su famosa obra El Abrazo de Amor del Universo, la Tierra (México), Rivera, Yo y el Sr. Xolotl de 1949.

Por otra parte en el plafón donde se prolonga el cielo, Rivera representó nuevamente a un desnudo femenino que demuestra que el artista continuaba elaborando el arquetipo femenino tal y como lo había comenzado a explorar en la Secretaría de Salubridad y en Chapingo, pero con más dinamismo, simbolizando ahora en palabras del mismo Rivera no sólo "la Fertilidad de la tierra" sino también "la interconexión natural de la Agricultura y la Industria" (Rivera y March, 1960/1963, p. 138).

\section{La Gran Diosa}

En otras obras de Rivera, las contradicciones internas del arquetipo materno dan muestras de una disociación, entre la diosa benevolente y la peligrosa, tal como aparece en las imágenes de las grandes diosas de distintas culturas a través del tiempo, y muy particularmente de la prehispánica, con la que tan profundamente se identificaba nuestro artista.

\footnotetext{
${ }^{9}$ Señala Antonio Rodríguez que "a este mural se le criticó el hecho de que el personaje central fuera representado concretamente por una persona real (una campeona de tenis), y no por una persona indefinida, más capaz -según los críticos- de representar a la generalidad de la región." Pero que, sin embargo, "Rivera demostró que Helen Wills Moody había dado a conocer a California en el mundo y que por su inteligencia, juventud y vigor bien merecía ser tomada como símbolo de toda la entidad. La belleza de la obra y los argumentos del autor se impusieron sobre lo poco consistente de la crítica" (1999, p. 95).
} 
Dentro del complejo ciclo mural de La industria de Detroit o el hombre y la máquina o Detroit dinámico (1932-1933), en el así llamado patio central o "Rivera hall" del The Detroit Institute of Arts en Michigan, Estados Unidos, Rivera se propuso glorificar el desarrollo industrial norteamericano. A pesar del aparentemente lejano tema principal, una vez más, el arquetipo femenino hizo su presencia en varias y expresivas formas, otorgando un nuevo grado de abstracción y consiguientemente de "verdad" a la narración histórica realista.

El ciclo comienza en la pared este, donde con la intención de representar el origen de la tecnología y también el de la vida, nuevamente a través de una narrativa paralela, Rivera incluyó su ya clásica asociación del desnudo femenino con la fertilidad de la tierra y la abundancia, esta vez a través de bellas estilizaciones curvilíneas de dos mujeres, una morena y otra rubia, que respectivamente sostienen con sus manos frutos y espigas de trigo.

Durante su larga vida con Frida, la pareja de artistas experimentó entre otros muchos tristes avatares, la interrupción de varios embarazos que por varias y complejas razones médicas no pudieron llegar a buen término. Si bien el sufrimiento causado por las múltiples pérdidas es bien conocido en el caso de Frida, quien realizó conmovedoras pinturas sobre el tema, en las biografías de Rivera, y especialmente en los estudios sobre su obra, el dolor personal en relación con estas experiencias trágicas no suele ser tratado.

Sin embargo, en el ciclo mural de Detroit Rivera incluyó varias imágenes sobre el tema de la gestación, principalmente, en el muro este "la célula germinal" asociada como en Chapingo con el bulbo de una planta y con la Tierra; mientras que en las paredes norte, el artista representó imágenes de embriones sanos en formación, contrapuestas a células asfixiadas por un gas venenoso, y en el lado sur, una escena de cirugía, pinturas todas que parecen denotar, como en el caso de Frida, una intención no sólo alegórica y abstracta sino más bien, autobiográfica y catártica.

Las imágenes de células y embriones en formación, representados con una original visión de rayos $\mathrm{x}$ de Detroit son un ejemplo de la curiosidad insaciable por los orígenes de la vida, patente ya desde su disección de una rata cuando era un niño pequeño al que me referí más arriba en el texto, entendida claramente en su aspecto dual y contradictorio, en particular su ineludible cercanía con la muerte que Rivera conocía tan bien desde su propia infancia y que revivía ahora a través de los frustrados embarazos y el dolor de su joven esposa. El tema volvería a aparecer más adelante, en los frescos de Cárcamo del Río Lerma con nuevos bríos y asociaciones simbólicas.

El arquetipo femenino, en relación con la dualidad propia de la Gran Diosa apareció también en Detroit, en la monumental y antropomórfica maquinaria representada en el muro sur, que la mayor parte de los especialistas coinciden en señalar fue inspirada no sólo por las maquinarias industriales que Rivera conoció en las plantas fabriles que visitó, sino también por la poderosa forma y el profundo contenido simbólico de la grandiosa escultura azteca de la Coatlicue, del Museo Nacional de Antropología de la ciudad de México.

Decía el crítico Walter Pach que Rivera pensaba en la Coatlicue cuando realizó los frescos pues "el espíritu de vida y muerte de los antiguos mexicanos se manifestaba en el fresco -y en un parecido extraordinario- en la máquina vibrante que simboliza en tan alto grado la vida actual" $(1951$, p. 208). Algunos años más tarde, en 1940, en su mural Unidad panamericana, para el City College de San Francisco, también en los Estados Unidos, Rivera creó una nueva imagen de la Coatlicue, esta vez mitad 
piedra y mitad máquina, como oposición y complemento entre la espiritualidad y la materialidad, la visión humanista y la científica y tecnológica, el pasado indígena y el progreso. En el centro de la imagen híbrida, una representación de la vida y la muerte, enfatiza el significado simbólico principal de la figura. En la exposición homenaje a la labor artística de los 50 años de Rivera en 1949, su comisario, el extraordinario museógrafo Fernando Gamboa, literalmente instaló dicha escultura entre las obras del muralista, resaltando así la continuidad del arte mexicano aludida por Rivera en las obras aquí referidas y confirmada en la muestra al compartir tan dignamente el espacio real.

Para el historiador Justino Fernández la Coatlicue simboliza la vida y la muerte, y como su figura "se levanta sobre un eje vertical, sobre el que se cruza otro horizontal que pasa por las manos y forma, virtualmente, una cruz" se relaciona también con "las cuatro direcciones" (1958/1989, pp. 35-37). En la parte inferior del panel Rivera incluyó un retrato de Frida, para aquel entonces ya reconocida en el mundo artístico, separada del artista y vuelta a casar con él durante la realización del mural, que en su actitud rígida y su atavío popular semeja la encarnación misma de la altiva diosa, mientras él se autorretrató rodeando el árbol de la vida de la mano de la actriz Paulette Goddard cerca de una parejita de niños que con su muñeca semejan una familia modelo tipo. ${ }^{10} \mathrm{El}$ arquetipo femenino de la buena madre y la fertilidad, aparece claramente separado del de la gran diosa, creadora de vida y destructora a la vez, representado por la Coatlicue y encarnado en la misma Frida.

\section{El agua}

Años más tarde, en 1951, cuando Rivera tenía ya 65 años de edad, el arquetipo siguió evolucionando y recuperando su más profundo aspecto bondadoso a través del simbolismo del agua. En el ciclo titulado El agua origen de la vida (1951) del Cárcamo del Río Lerma en el Bosque de Chapultepec de la ciudad de México, Rivera se acercó al tema, de acuerdo con la función principal de la estructura como sistema de distribución del precioso líquido, pero también como excusa para expresar su visión particular del arquetipo para aquel entonces.

En la entrada, alrededor de un estanque, Rivera representó a Tlaloc, el dios azteca de la lluvia y la fertilidad, con una figura escultórica cubierta con mosaico que se continúa por los alrededores del parque a través de líneas dinámicas y fluidas que destacan la función del agua como la fuente principal de la vida. En la cisterna, el piso y las paredes de la cámara de distribución, Rivera representó un mundo fantástico de amebas, estrellas de mar, moluscos, anfibios, peces y otras formas primitivas de vida, ${ }^{11}$ pasando por otros seres más desarrollados hasta llegar a dos figuras humanas monumentales que representan a las razas asiática y africana. En la pared del frente aparecen los retratos de los obreros e ingenieros que hicieron posible la obra de ingeniería, escenas con personas trabajando y disfrutando del agua junto a otras sufriendo por su falta. El programa iconográfico sugiere así, metafóricamente, que el poder benéfico de Tlaloc volvió a la vida en el mundo moderno gracias al trabajo de los técnicos y trabajadores que participaron en la obra.

\footnotetext{
${ }^{10}$ Cuando Rivera llegó a San Francisco ya estaba separado de Frida y huía de México tras el primer atentado cometido contra León Trotsky con quien desde hacía tiempo mantenía importantes diferencias políticas y personales. Durante la creación del mural, el 20 de agosto de 1940 Trotsky fue finalmente asesinado, en septiembre Frida viajó a San Francisco y en diciembre, la legendaria pareja volvió a casarse con la condición impuesta por Frida de abstenerse de mantener relaciones sexuales.

${ }^{11}$ Rivera parece haber basado su documentación en la teoría del científico soviético Alexander I. Oparin sobre el origen de la vida en la tierra.
} 
El agua es una parte esencial de la mayoría de las creencias y prácticas rituales a través del tiempo y del espacio y ya había aparecido frecuentemente en la pintura mural de Rivera a través del tiempo. Su variada significación y simbolismo se relaciona principalmente con tres aspectos principales: como fuente de vida, medio de purificación y centro de regeneración. Gaston Bachelard, en su obra El agua y los sueños: ensayo sobre la imaginación de la materia, publicado originalmente en 1942, considera que la imaginación humana atribuye al agua un carácter femenino y maternal.

[E]l agua hincha los gérmenes y hace surgir las fuentes. El agua es una materia que por todas partes vemos nacer y crecer. La fuente es un nacimiento irresistible, un nacimiento continuo. Imágenes tan grandes marcan para siempre el inconsciente que gusta de ellas y suscitan ensoñaciones $\sin$ fin (1942/2003, p. 27)

Dichas ensoñaciones animan la obra de Rivera.

La fascinación de Rivera con el origen de la vida humana aparece en este trabajo en dos formas diferentes y complementarias: en las figuras humanas representadas en las paredes laterales y en la configuración espacial de la misma obra. La figura femenina que simboliza a la raza asiática, está representada con una visión de rayos $x$ como la que había utilizado en Detroit, que deja ver ahora el embrión que contiene, como símbolo tangible de la fertilidad. Dos anguilas que sugieren las trompas de falopio parecen resguardar a unos espermatozoides que nadan rumbo al óvulo, dos cigotos inician los procesos de la división celular, y en el centro, el embrión que comienza a crecer en el vientre femenino. Las anguilas recuerdan al uroboros griego, símbolo que expresa la unidad de todas las cosas, las materiales y las espirituales, lo consciente y lo inconsciente, que nunca desaparecen sino cambian de forma perpetua en un ciclo eterno de destrucción y nueva creación.

Para Betty Ann Brown, la figura femenina podría significar la diosa azteca Chalchiuhtlicue, esposa de Tlaloc (1985, p. 141). Como diosa de las aguas que fluyen se creía que presidió uno de los soles del período cosmogónico, que acabó con una inundación que convirtió a los hombres en peces. En su aspecto positivo ella dirigía la ceremonia del baño ritual de los niños, al que los primeros observadores españoles compararon con el sacramento cristiano del bautismo. Resulta interesante señalar que el primer nieto del artista, nacido poco tiempo antes, fue bautizado por aquel entonces de acuerdo con el rito cristiano.

La referencia autobiográfica concreta en el ciclo mural conlleva un profundo sentido del humor, pues como señala Claudia Ovando, en el lado de la mujer, como parte del ciclo evolutivo, Rivera incluyó la figura de un sapo de barriga con saltones ojos "riverianos", que alude visualmente al sobrenombre de sapo-rana que Frida había impuesto al artista, nadando hacia uno de los senos de la figura materna (1999, p. 23).

Por otra parte, no falta la alusión al rol masculino en el proceso reproductivo que caracteriza a la obra Rivera pues la figura masculina, que representa a la raza negra, ${ }^{12}$ muestra una extraña flor que de acuerdo con Antonio Rodríguez es en donde Rivera:

\footnotetext{
${ }^{12}$ La caracterización de la pareja humana como asiática y africana se corresponde con las teorías en boga por aquel entonces que posteriormente formalización Richard Leaky señalando dichos continentes como la cuna del Hombre y también como reacción contra las teorías fascistas que propugnaban por la supremacía de la raza aria.
} 
partiendo de datos científicos alcanza la más alta libertad creativa y se convierte en fruto de la invención, tiene un antecedente cercano en La flor de la vida, el espléndido cuadro de Frida Kahlo en el cual la artista por medio de hojas, ramas, nervaduras, cálices, pistilos, estambres, etcétera, sugiere con la máxima sutileza, los órganos sexuales humanos en el acto de la fecundación y de un explosivo orgasmo (1987/1999, p. 146).

De la flor sale la cola de un ajolote que una vez más se continúa en el cuerpo de un batracio.

\section{El útero}

En cuanto al tema de la vida en relación con la conformación espacial resulta interesante destacar las manos gigantescas que Rivera representó sobre una abertura en forma de arco a la entrada de la cisterna que resaltan la metáfora del nacimiento, pues una vez más, en palabras de Antonio Rodríguez, "dentro de este contexto creativo, la boca del túnel, por donde irrumpe el agua de los lejanos manantiales, es como la salida de un útero que el pintor convirtió en fuente [artística] de la vida" (1987/1999, p. 146).

Paracelso, el médico y alquimista renacentista admirado por Rivera, creía en una matriz cósmica, pues para él, además del macrocosmos y el mundo sublunar que habitábamos, había un tercer universo, el útero, que poseía por sí mismo los cuatro elementos: aire, agua, tierra y fuego (1995, p. 77). Los dibujos anatómicos de Leonardo da Vinci reflejan con extraordinaria belleza esa misma idea. La combinación del nacimiento y las aguas aparece frecuentemente en la mitología a través de las expresiones "surgido de las ondas" o "salvado de las aguas" que tradicionalmente funcionan como metáforas del parto tal y como Frida Kahlo lo simbolizó en su obra sobre la historia bíblica de Moisés.

El útero de la Tierra es un símbolo característico de la Gran Madre como la puerta de acceso a lo sagrado que convierte al nacimiento en un renacimiento hacia un tipo de vida más elevado. Señala Mircea Eliade que como:

principio de lo indiferencial y de lo virtual, fundamento de toda manifestación cósmica, receptáculo de todos los gérmenes, las aguas simbolizan la sustancia primordial de la que nacen todas las formas y a la que vuelven, por regresión o por cataclismo. Fueron al comienzo, retornan al final de todo ciclo cósmico, existirán siempre -aunque nunca solas- porque las aguas son siempre germinativas, encerrando en su unidad no fragmentada las virtualidades de todas las formas. En la cosmogonía, en el mito, en el ritual, en la iconografía, las aguas llenan la misma función, cualquiera que sea la estructura de los conjuntos culturales en los que se encuentran: preceden a toda forma y sostienen toda creación. La inmersión en el agua simboliza la regresión a lo preformal, la regeneración total, el nuevo nacimiento, pues una inmersión equivale a una disolución de las formas, a una reintegración en el modo indiferenciado de la preexistencia; y la salida de las aguas repite el gesto cosmogónico de la manifestación formal, el contacto con el agua implica siempre la regeneración; por una parte, porque la disolución va seguida de un "nuevo nacimiento", por otra parte porque la inmersión fertiliza y aumenta el potencial de vida y de creación” (1964/1982, p. 178). 
El ciclo de Cárcamo de río Lerma, uno de los favoritos del propio artista, que lo describió como su encargo "más fascinante", resume el renacimiento espiritual experimentado por Rivera al expresar el arquetipo femenino de la Gran Diosa de forma tan explícita y poética a la vez.

Tan sólo dos años más tarde, en La historia de la medicina en México: el pueblo en demanda de salud (1953-54), realizado para el Instituto Mexicano del Seguro Social (IMSS) Rivera continuó dando forma a su plena comprensión del arquetipo femenino en su forma de Gran Diosa. Como tema principal, de acuerdo con la función hospitalaria del edificio, Rivera plasmó los conocimientos médicos propios de la etapa prehispánica y de los tiempos modernos. La imagen central, fue copiada y monumentalizada por el artista a partir de la representación de la diosa Tlazolteotl, incluida en el Códice Borbonicus, del siglo $\mathrm{XVI}$, donde como diosa de la tierra aparece cubierta con la piel de Xipe-Totec, nuestro Señor el Desollado, dando a luz a Centeotl, el dios del maíz. Su posición central y su tamaño monumental sirven al artista para unir las dos secciones principales del mural, el lado prehispánico y el moderno, sugiriendo así la continuidad del pueblo mexicano a través del tiempo y también la universalidad y relevancia del tema del nacimiento y la regeneración que ella simboliza.

Por otra parte, resulta interesante recordar que la diosa, tenía también una connotación moral, pues se decía que al comer los desechos purificaba los pecados humanos y que existía un rito de confesión ligado a su culto (Vaillant, George, 1941, p. 146). Su dualidad puede asimilarse fácilmente a la justificación cristiana del acto sexual como el medio de atender al comando divino de multiplicarse. Como los indios que esperaban a una edad avanzada para confesarse (Gray, Herbert, 1964, p. 78), Rivera usó su último mural, para revelar su interés, sus sentimientos encontrados y su inmensa admiración de toda su vida en relación con el sexo, la reproducción y el arquetipo femenino.

La diosa vuelve a aparecer en el mural, esta vez como copia de una escultura azteca, columpiándose de una de las ramas del árbol amarillo de la vida que enmarca, junto con el árbol rojo de la salud, los límites laterales de la composición, a los que volveremos más adelante. Resulta interesante señalar que tiempo atrás, refiriéndose a Mi nacimiento de Frida, Rivera había dicho que el único antecedente de la notable pintura de su esposa había sido el escultor azteca de Tlazolteotl. Inspirando su composición en dicha extraordinaria escultura azteca, Rivera le rendía un homenaje no sólo a la cultura prehispánica, sino también a su idolatrada esposa Frida, que para aquel entonces comenzaba a mostrar testimonios certeros del creciente deterioro físico que poco tiempo después la llevaría a la muerte.

El tema del parto, aludido ya explícitamente por la figura doble de Tlazolteotl, sirve a Rivera para contraponer, de acuerdo con su característica visión romántica del pasado prehispánico, un parto natural y feliz, frente a una operación cesárea, en medio de un ascético y frío contexto hospitalario, en el mundo moderno, el cual ineludiblemente trae a la mente las imágenes inmortalizadas por Frida de la operación césarea sufrida por la pareja en sus años de Detroit. Por otra parte, las mujeres que asisten el parto prehispánico muestran los rasgos faciales de las hijas de Rivera, Guadalupe y Ruth, mujeres para aquel entonces ya adultas, con quienes el artista mantenía una buena relación. Representadas en el mural, ejerciendo el oficio de partera, al que se había dedicado la propia madre del artista, re-ubicadas en el utópico mundo prehispánico de Rivera, parecen significar su reconciliación simbólica con el arquetipo femenino y con los misterios del nacimiento en relación con su temprana imagen materna, re-elaborada a partir de su experiencia como abuelo. 


\section{El árbol}

Como señalé más arriba en el texto, el mural está enmarcado por dos figuras arbóreas, otro de los aspectos con los que comúnmente se simboliza al arquetipo femenino, pues como imagen de la vida en perpetua evolución, suelen asimilarse con la Gran Diosa, con su fuerza creadora, nutritiva y devoradora a la vez.

El árbol como arquetipo femenino fue muy frecuente en la obra de Rivera. En numerosos ejemplos de sus pinturas de caballete, las ramas entrelazadas y sus brotes parecen connotar más o menos evidentes referencias al cuerpo femenino, a la sexualidad y a la regeneración. Según numerosos mitos el hombre desciende de los árboles y muchas veces el héroe está encerrado en el árbol materno: Osiris yace muerto dentro de un cedro, Adonis nace del mirto y Atis se asocia con el pino. Dentro de su producción mural, el árbol también había aparecido en numerosas ocasiones: en el panel Xochipili y adoradoras (1928) de la escalera de la SEP, Rivera los había representado como amplificación de los cuerpos de las figuras femeninas reunidas para adorar a la deidad azteca de las flores, el amor, la belleza, y la fertilidad; en el Entierro del líder revolucionario del salón de actos de Chapingo el árbol había aparecido en su aspecto de símbolo del ciclo de la vida, la muerte y la regeneración en relación con el proceso de transformación social de la Revolución; y en el mural la Unión Panamericana, en su aspecto simbólico como árbol de la vida.

Los extraños árboles andróginos representados por Rivera en La historia de la medicina en México, el amarillo de la vida y el árbol rojo de la salud, con frutas o múltiples glándulas mamarias parecen derivar de la figura del árbol nodriza de los aztecas. Según la antropóloga Doris Heyden, para la mitología náhuatl en el punto cardinal del Este, existía un árbol erguido con senos del cual se alimentaban los niños que morían en la cuna, que no iban al reino de los muertos sino a la tierra del "agua con flores", al Xochiatlalpan, al "paraíso de la vegetación" (Heyden, Doris, 1983, p. 85). Dicha autora señala también que el árbol con senos es identificado en el Códice Vaticano Ríos, con la diosa del sustento Tlazoltéotl, la diosa madre prehispánica incluida dos veces en el mural de Rivera. Considerando la dramática historia personal del artista en relación con la reproducción, partiendo de su mismo nacimiento, la prematura muerte de su hermano gemelo, la de su primer y único hijo varón, y las múltiples pérdidas de su esposa Frida, su representación del árbol nodriza azteca en su último mural parece ofrecer una sanadora esperanza para los infantes, al mismo tiempo que una oportunidad de reivindicación para el pintor que a los 67 años de edad comenzaba a prepararse, de forma consciente e inconsciente, para la muerte, que lamentablemente habría de llegarle tan sólo tres años más tarde.

\section{Conclusiones}

El mitógrafo norteamericano Joseph Campbell, seguidor de Jung, analizó la hipótesis según la cual la situación perturbada de la sociedad occidental en los últimos tiempos pudiera deberse, por lo menos en parte, al descrédito progresivo en que han caído las mitologías y a la racionalización sufrida por ellas, con lo cual las imágenes simbólicas se ven obligadas a refugiarse en su lugar de origen, el inconsciente (1994).

El individuo, aislado, tiene que enfrentarse así a los dilemas que en otros tiempos se trabajaban a través de los sistemas mitológicos colectivos. Diego Rivera, conciente de las más serias de las problemáticas que aquejaban a su mundo contemporáneo, muchas de las cuales todavía siguen aquejando al nuestro, 
reconoció, no sólo la necesidad de recuperar la memoria de la historia nacional, sino también la de retomar algunos de los símbolos y de los sistemas mitológicos colectivos característicos de otras épocas, para entretejerlos en su obra con sus característicos temas históricos y políticos, que así recuperan no sólo su valor local y temporal, sino también uno más universal y eterno.

Señalaba Thomas Mann que "el mito es la legitimación de la vida, ya que en él y sólo por él halla conciencia de sí misma, su justificación y consagración" (Mann, 1937, pp. 63-64).. Las imágenes de madres humanas y divinas, vividas, imaginadas, estudiadas y representadas por Rivera en su obra mural, principalmente en relación con sus experiencias personales como hijo, esposo, amante, padre y abuelo, y con el poder creador/destructor personificado por las diosas del México prehispánico, nos ayudan a entender no sólo algunos de los aspectos principales de su singular personalidad humana, y de algunos de los determinantes particulares de carácter individual y cultural que influyeron en su singular cosmovisión, sino también, y principalmente, algunos de los arquetipos que caracterizan al espíritu humano. La actualización del arquetipo femenino llevada a cabo por Rivera en sus obras, a través de las imágenes de la buena madre, la gran diosa, la serpiente, el agua, el útero y el árbol, nos ofrece la posibilidad de conectarnos con el inconsciente colectivo, abriéndonos así a nuevas y más plenas experiencias no sólo de índole personal sino social.

En su inteligente y conmovedor retrato de Rivera, escrito para la exposición homenaje de 1949, Frida Kahlo expresó el arquetipo femenino, lógicamente, desde su posición como mujer, demostrando un muy profundo entendimiento de los aspectos maternales y divinos que Rivera simbolizó a través de su obra, vistos ahora desde el otro lado del espejo. Decía entonces Frida que:

La forma de Diego es la de un monstruo entrañable, al cual la abuela, la Antigua Ocultadora, la materia necesaria y eterna, la madre de los hombres, y todos los dioses que éstos inventaron en su delirio, originados por el miedo y el hambre, LA MUJER, entre todas ellas -YO- quisiera siempre tenerlo en brazos como a un niño recién nacido (1951, p. 38)

Este poderoso volcán, que fue Diego Rivera con su talento, ardor y fuerza vital extraordinarias provocó, calcinó, aturdió y demolió, pero también amó, creó, creyó, construyó y dio vida a extraordinarias, penetrantes y poéticas imágenes que trascienden sus propias pasiones y las de su tiempo y lugar histórico. Su obra nos ayuda a re-conectarnos con la sacralidad de lo humano, y en particular con el extraordinario poder del arquetipo femenino, presente a través de la historia en infinidad de mitos y rituales de diferentes épocas y lugares, pero lamentablemente denigrado o ausente en la mayor parte de las representaciones artísticas modernas y que Rivera supo expresar de forma erudita y sensible a la vez.

\section{Referencias}

Bacherlard, Gaston. (1942/2003). El agua y los sueños. Ensayo sobre la imaginación de la materia. México, D.F.: Fondo de Cultura Económica

Beloff, Angelina. (1986). Memorias. México, D.F., SEP y UNAM. 
Brown, Betty Ann. (1985). El pasado idealizado: la utilización de la imaginería precolombina por Diego Rivera. En Newman Helms, Cynthia (editora), Diego Rivera A Retrospective (pp. 149-165). Detroit: Detroit Institute of Arts.

Campbell, Joseph. (1994). Los mitos: su impacto en el mundo actual. Barcelona: Editorial Kairós.

Douglass, Claire. (1990). The woman in the mirror, analytical psychology and the feminine. Boston: Sigo Press.

Eliade, Mircea. (1964/1982). Tratado de historia de las religiones. México, D.F.: Era.

Fernández, Justino. (1958/1989). Arte Mexicano de sus orígenes a nuestros días. México: Porrúa.

Gray, Herbert. (1964). The Mythology of all Races. Nueva York: Cooper Square.

Heyden, Doris. (1983). Mitología y simbolismo de la flora en el México prehispánico. México, D.F.: UNAM, Instituto de Investigaciones Antropológicas.

Jung, Carl G. (1934/2002). Sobre los arquetipos de lo inconsciente colectivo. En C. G. Jung. Los arquetipos y lo inconsciente colectivo. OC. 9. Barcelona: Trotta.

Kahlo, Frida. (1951). Retrato de Diego. En Diego Rivera, cincuenta años de labor artistica (pp. 37-42). México: INBA.

Mann, Thomas. (1937). Freud y el porvenir. Buenos Aires: Panapress.

Neumann, Erich. (1974). The Great Mother: An Análisis of the Archetype. Princeton: Princeton University Press.

Ovando, Claudia. (1999). Diego Rivera: El agua, origen de la vida. México: Círculo de Arte, Conaculta.

Pach, Walter. (1951). Relaciones entre la cultura norteamericana y la obra de Diego Rivera. En Diego Rivera, cincuenta años de labor artistica (pp. 207-210). México, D.F.: INBA.

Paracelso. (1995). Textos esenciales. Madrid: Ediciones Siruela.

Rivera, Diego; March, Gladys. (1960/1963). Diego Rivera. Mi arte, mi vida. México, D.F.: Herrero.

Rodríguez Mortellaro, Itzel. (2004). Coatlicue asiste al homenaje a Diego Rivera: la creación de significados culturales en el discurso museográfico de Fernando Gamboa. Extraído el 18 de octubre de 2010 de Discurso Visual de http://discursovisual.cenart.gob.mx/anteriores/dvwebne05/entorno/entitzel.htm

Rodríguez, Antonio. (1987/1999). Diego Rivera. Pintura mural. México, D.F.: Fondo Editorial de la Plástica Mexicana y Fideicomiso en el Banco Nacional de Comercio Exterior.

Roura, Alma Lilia. (1999). Aguas, Diego. ¡Ahí Viene Lupe!. En Memorias del Congreso Internacional de Muralismo. Reflexiones historiográficas y artísticas (pp. 119-147). México, D.F.: Antiguo Colegio de San Ildefonso.

Rowland, Susan. (2002). Jung a feminist revision. Malden: Blackwell Publishers Inc. 
Saiz, Jesús; Fernández, Beatriz y Álvaro, José Luis (2007). De Moscovici a Jung: el arquetipo femenino y su iconografía. Athenea Digital, 11, 132-148. Extraído el 18 de octubre de 2010, de http://psicologiasocial.uab.es/athenea/index.php/atheneaDigital/article/view/385/330.

Tibol, Raquel. (2007). Diego Rivera luces y sombras. México: Random House Mondadori.

Vaillant, George. (1941). Aztecs of Mexico: Origins, Rise and Fall of the Aztec Nation. Garden City: Doubleday.

Wolfe, Bertram. (1963/1997). La fabulosa vida de Rivera Rivera. México, D.F.: Editorial Diana.

\section{Historia editorial}

Recibido: 09/10/2009

Aceptado: 19/10/2010

\section{Formato de citación}

Comisarenco Mirkin, Dina (2010). Diosas y madres, el arquetipo femenino en Diego Rivera. Athenea Digital, 19, 191-212. Disponible en http://psicologiasocial.uab.es/athenea/index.php/atheneaDigital/article/view/670.

\section{(c) SORE RIGHIS RESERVED \\ Este texto está protegido por una licencia Creative Commons.}

Usted es libre de copiar, distribuir y comunicar públicamente la obra bajo las siguientes condiciones:

Reconocimiento: Debe reconocer y citar al autor original.

No comercial. No puede utilizar esta obra para fines comerciales.

Sin obras derivadas. No se puede alterar, transformar, o generar una obra derivada a partir de esta obra. 